\title{
Crimes Against Cultural Heritage in Timbuktu
}

On the $3^{\text {rd }}$ March 2016, Ahmed Al-Faqi Al-Mahdi sat in a courtroom at the International Criminal Court (ICC) in The Hague. He stated that he was a Tuareg/Tamachek man of about 40 years of age, born in a village near Timbuktu. He also stated that he wanted to be addressed in Arabic and that he understood the accusations made against him. He is facing charges of directing attacks against nine mausoleums and the Sidi Yahia mosque in Timbuktu $^{1}$ and has became the first person in the history of the ICC to be prosecuted for the destruction of cultural sites. He is also the first person in the Court's history to plead guilty. His trial will take place on the $22^{\text {nd }}$ August 2016.

Al-Mahdi (also known as Abou Tourab) is a member of the Islamic extremist group Ansar Dine, and allegedly part of the group's Islamic police and head of 'Hesba', a morality brigade. Ansar Dine, together with Al-Qaeda in the Islamic Maghreb (AQIM) occupied Timbuktu in 2012. A military coup in the capital Bamako in March 2012 gave rise to the conditions for the occupation by the radical Islamists, who, in alliance with Tuareg rebels, captured large parts of northern Mali in the name of a Tuareg homeland (Azawad) and in order to impose of a 'pure' form of Islam on the population.

The atrocities in the north of Mali were well covered by the international press because of the brutality of the extremists and the banning of music in a location well known for its festival in the desert. The extremists also destroyed ancient manuscripts housed in the Ahmed Baba Centre. The attacks could therefore be seen as targeting a uniquely African intellectual tradition.

The court proceedings in The Hague are taking place against a backdrop of a precarious peace plan for Mali, the 'Accord D'Alger', signed in 2015. The accord has been criticised because of the lack of representativeness of its

\footnotetext{
${ }^{1}$ The before and after photos of the damaged monuments can be found at: https://www.icc-
} 
signatories, Bamako's limited perceived legitimacy in the north, persistent insecurity and the absence of transitional justice and reconciliation procedures (Pezard \& Shurkin, 2015). Matters are further complicated by the ongoing battle for control over lucrative illegal trade routes in the north of Mali (cocaine, arms, tobacco, people smuggling) and of particular relevance in the case of Al-Mahdi, a battle over the appropriate form of Islam found in Mali.

In March 2015, The Worldwide Movement for Human Rights asked the ICC to widen the charges against Al-Mahdi to include torture, arbitrary detentions, rape, forced marriage, sexual slavery and other sexual violence. For now, the ICC is limiting its charges to the destructions of religious sites. In reference to the events, the ICC prosecutor, Fatou Bensouda, explained:

"Let us be clear: what is at stake is not just walls and stones. The destroyed mausoleums were important, from a religious point of view, from an historical point of view, and from an identity point of view"3

Since 1988, Timbuktu's mosques and mausoleums have been on UNESCO's World Heritage List and are therefore not only powerful local religious sites but have become symbols of a universalist humanist western discourse about identity. As the Director General of UNESCO, Irena Bokova, commented at the time of the launch of a fund for the rehabilitation of Mali's cultural heritage in 2013:

"When a world heritage site is destroyed because of stupidity and violence the whole of humanity feels that it has been deprived of part of itself, that it has been injured" 4

\footnotetext{
${ }^{3}$ http://www.ijmonitor.org/2016/03/al-faqi-declines-to-make-submissions-in-northern-malicase/ (retrieved 6 ${ }^{\text {th }}$ March 2016) http://www.unesco.org/new/en/media-services/world-heritage-37th-session/whc37details/news/international_experts_and_decision_makers_gathered_at_unesco_adopt_action_pla n_for_malis_cultural_heritage_and_manuscripts/ (retrieved 6 $6^{\text {th }}$ March 2016)
} 
The masons in Timbuktu have since restored the destroyed mausoleums and repaired the mosque using UNESCO funds. A ceremony was held in 2015 to re-consecrate the sites and hand back the keys to their traditional owners.

\section{Why now?}

The International Criminal Tribunal for the former Yugoslavia (ICTY) was a United Nations law court set up in 1993 to investigate the crimes that took place during the conflict in the Balkans, including the destruction of cultural heritage. Due to limited remit of the ICTY, the need for a permanent, treaty based, international criminal court was identified. Since the ICC's creation in 2002, war criminals can be tried personally for destructive acts against cultural heritage.

The international outcry following the destructions in Timbuktu came after UNESCO's and other international bodies' powerlessness in the face of high profile 'performative' destructions of cultural heritage around the world. These include the 2001 destructions of the Buddhas of Bamiyan in Afghanistan by the Taliban, the attacks against the Mosul museum and at Nimrud in Iraq in 2015 by the Islamic State of Iraq and the Levant (ISIL) and recent destructions in Palmyra, Syria, again by ISIL. It is therefore important to UNESCO for the ICC to make an example of the Timbuktu case in order to assert the institution's credibility as a defender of global cultural heritage.

It is not surprising that the first 'crimes against cultural heritage' to be tried at the ICC are crimes against a UNESCO World Heritage Site. The destructions can be seen to be about both the forms of Islam that are considered legitimate and the forms of global politics that are considered legitimate. According to a BBC journalist at the time of the destructions, an Ansar Dine spokesman, Sanda Ould Boumama, told the AFP news agency the mausoleums would be 
destroyed, "all of them, without exception. God is unique. All of this is haram (forbidden in Islam). We are all Muslims. UNESCO is what?"5

\section{Islam in Mali}

Timbuktu is known as the City of 333 Saints and during its golden age in the 15th and 16th centuries was a centre for Islamic learning. Despite this rich history, the site is viewed as idolatrous by Islamic extremists. The worshipping of mausoleums in Timbuktu and across Mali is part of a Sufi tradition in Islam. Children in Timbuktu and Djenné (Timbuktu's sister city) attend Qur'anic schools and learn to recite the Qur'an by heart, usually without learning Arabic. In this way, they learn to be Muslim through embodied practice. Marabouts (religious teachers) engage in petitionary prayer and the preparation of amulets to ward off danger. These practices, as well as the performance of music, sport and many interdictions around dress and sexual conduct were all reasons for the brutal assaults by Ansar Dine and AQIM on the populations in northern Mali.

The international community has historically seen Mali as a bulwark against radical Islam (Soares, 2005). The distinction between so-called 'Black Islam' found in Mali and so-called 'Mediterranean Islam' (brought over from the Arab peninsula), was noted as early as 1906 by Robert Arnaud, the director of the French Colonial Office of Muslim Affairs (Badru, 2006). Arnaud stated that the French colonial administration would do well to support 'Black Islam' in Mali as he considered it less dangerous to the colonial agenda than 'Mediterranean Islam'.

Throughout Mali's history, jihads and counter-jihads have led to the destruction and rebuilding of mosques, in Timbuktu and in Djenné. In Djenné, the current Great Mosque is the third to be built on the central site and the small neighbourhood mosques that were once found around the town have all

${ }^{5}$ http://www.bbc.com/news/world-africa-18657463 (retrieved 6th March 2016) 
been destroyed (Bourgeois, 1989). In this context, the reconstruction of the Timbuktu shrines and mosque with UNESCO money is yet another chapter in this history. For the ICC and UNESCO however, the destructions in Timbuktu in 2012 are the latest attacks by Islamic extremists on global cultural heritage.

\section{UNESCO in Mali}

In previously published work (2013), I chart the rise of recognition of cultural heritage by UNESCO in post-colonial Mali. Before UNESCO recognition, Mali's iconic mud brick architecture had been part of the French psyche due to the writings of early European explorers, iconic postcards and the reproduction of the Mosque and a typical Djenné street at the International Colonial Exhibition in Vincennes in 1931. Mali also has a strong international reputation for its photography and its music and before the events of 2012 was a popular destination for cultural tourism. The destruction of tourism in Mali, in common with large parts of North Africa, has been a deliberate and devastating part of the extremists' strategy.

The declaration of three UNESCO World Heritage sites in Mali in 1988 and $1989^{6}$ was largely due to the interests of Mali's ex-President, Alpha Oumar Konaré, who is a trained archaeologist and who has excavated at the site of Djenné-Djeno (next to the current town of Djenné). He acted as consultant for UNESCO (1981-92) and as President of the International Council of Museums (1989-92). He also became involved in an international effort to stop the looting of Mali's cultural heritage - a looting he equated with poverty. He stated that archaeological objects, like the young men of his country, were being dispersed around the world because Mali lacked the material means to keep them in situ (Konaré, 1995). This theme, of the conflation of people and objects, legitimately or illegitimately in or out of place, is part of the logic of UNESCO's World Heritage Project. Two of Mali's World Heritage sites, Timbuktu and the Tomb of Askia in Gao (declared a World Heritage site in 2004) are in the north of the country, thus enfranchising under Malian national

\footnotetext{
${ }^{6}$ Timbuktu, Djenné and Cliff of Bandiagara (Land of the Dogons)
} 
identity parts of the country that have been subject to Tuareg/Tamachek demands for self-determination.

UNESCO, like anthropologists, has long wrestled with the tension between universalism and relativism (Hylland-Eriksen, 2001). For example, through looking at Claude Levi-Strauss's relationship with UNESCO, one can chart a shift away from a call of universalism towards one of respect for difference (Joy, 2016). From its early post-war ambition of developing a global educational curriculum that would remove the possibility of human suffering on the scale seen during the Second World War, UNESCO has gradually moved towards a respectful ambivalence in the face of difference, even if the difference at times challenges the Universal Declaration of Human Rights. The unifying element of all the sites found on UNESCO's World Heritage List is 'Outstanding Universal Value', a slippery concept that describes sites that are 'so exceptional as to transcend national boundaries' and of importance for 'present and future generations of all humanity'. UNESCO's concern is not just for the here and now. It is also for a future humanity, not yet in existence, whose needs are thought to be fathomable by those present today and will include the need for a rich cultural heritage in order to flourish.

\section{The destruction of people and the destruction of things}

In 1990, long before the events of 2012, Timbuktu had already been put on UNESCO's list of 'World Heritage in Danger'. A committee of experts identified the threat of sand encroachment, a need to structurally consolidate the Djingareiber Mosque and to improve its terrace rainwater drainage systems. UNESCO found US\$45,138 to carry out the work. A further US $\$ 40,000$ dollars was found in 1995 to fund a ICCROM/CRATerre restoration project. In 2005, after yet another technical assessment, Timbuktu was removed from the list of 'World Heritage in Danger' only to find itself back on it in $\mathbf{2 0 1 2}$ where it has since remained.

UNESCO officials are very concerned with the material detail of the sites under its jurisdiction - in the case of Timbuktu and Djenné, the architectural 
techniques used, the size and shape of the bricks and the mix of ingredients that make up the mud bricks and the mud for rendering. This attention to detail is premised on a belief in 'authenticity' and the 'integrity' of a site. UNESCO conceptualises the sites of Timbuktu and Djenné like monuments to be preserved. This has caused some tension in the past, for example in Djenné, UNESCO officials strongly objected to the Imam's wishes to improve the Mosque by beautifying it with tiles and a new gate.

The biggest factor in the problems facing Timbuktu and Djenné has been extreme poverty and the inability of people to pay for the upkeep of their built environment (Joy, 2013). Cultural heritage projects have acted as both the catalyst and the proxy for much needed economic aid. By prioritising the protection of cultural heritage, UNESCO has mostly airbrushed out the lives of extreme poverty and poor sanitary conditions faced by the inhabitants of the sites. This causes grievances among the local population on a number of levels. First, there is the perception that the 'heritage elite' benefit disproportionately from the money being given in the name of cultural heritage and second, that the more pressing problem of economic marginality is being ignored.

A 2015 United Nations Development Programme (UNDP) report found that:

"Poverty and under-development create grievances that can easily be exploited by extremist groups, especially when such factors are combined with poor governance and the absence of even basic service delivery... the nexus between literacy, numeracy and the growth of radicalization has been observed in many areas across sub-Saharan Africa... This situation is aggravated by high-levels of unemployment, leaving many youth frustrated, lacking in viable prospects for the future and available for relatively easy recruitment into extremist groups, especially since most groups offer financial incentives and provide a sense of purpose." (UNDP, 2015, my emphasis) 
In March 2015, UNESCO launched a 'Unite4heritage' campaign in order to try and harness its own sense of purpose. It appeals to people all over the world to stand up to extremism by showing their support on-line (through selfies and social media). It prompts people to "stand up against extremism and radicalization by celebrating the places, objects and cultural traditions that make the world such a rich and vibrant place". ${ }^{9}$

However cultural heritage will always be vulnerable where people are vulnerable, as is the case for the looting of archaeological sites. As a young guide said to me in Djenné in 2004 at the time of the visit of the thenPresident Amadou Toumani Touré (ATT) "I don't need ATT, my ATT are the tourists" (Joy, 2011). If states are too weak or not motivated to provide meaningful livelihoods for people, other forces will step in.

\section{What is a crime against cultural heritage?}

The challenge for anthropologists studying material culture is to decide how to think about the Al-Mahdi trial. Does it matter if the same attention would not be given to the destruction of cultural heritage without the backdrop of war and damage to people? What are the moral consequences of conflating the destruction of people with the destruction of things? If a site can be restored and re-consecrated, what are the long-term material consequences of the destruction? Is the anxiety about authenticity of the site (brick shape, ingredients and methods used by different masons), about trauma to people caused by an assault on their religion, about global symbolism, or about all three things?

In the case of Timbuktu, a dramatic change of tone has occurred in UNESCO's concern for the site, from fears over sand-encroachment and authenticity, to a fight against global Islamic extremism. In part, the recent

\footnotetext{
${ }^{9}$ http://www.unite4heritage.org/en/unite4heritage-celebrating-safeguardingcultural-heritage (retrieved 6th March)
} 
violent damage is a validation of UNESCO's previous concerns. Yet paradoxically, sites are more of a target because of their link to UNESCO.

Ansar Dine's provocative statement 'UNESCO is what?' at the time of the destructions was answered by an ICC International Arrest Warrant for AlMahdi, which is in turn was countered by the kidnapping of Beatrice Stockly, a Swiss nun in Timbuktu in January 2016 by AQIM, who are demanding the release of Al-Mahdi if they are to spare her life. This series of events morally interweaves the lives of people and things, as if the destruction of one is equivalent to the destruction of the other.

While material culture theory has celebrated the multiple ways in which people and things can be entangled, the ICC is seeking one reading of events. UNESCO's acceptance of difference cannot stretch to radical extremism because there is a limit to difference that is reached when it infringes on other people's human rights and dignity.

In an interview with Janet Anderson on the $7^{\text {th }}$ March 2016, Bintou Founé Samaké, the president of a Malian NGO 'Women and Law in Development in Africa' explained why she attended Al-Mahdi's hearing:

" Those monuments were a reference point for an entire population, an entire nation and even the world ... It's as if - in Jerusalem - someone demolished the Wailing Wall with a bulldozer. That would be the end of the world. So those monuments, that's what they represent for us. It's as if someone had crushed our honour, our dignity." ${ }^{10}$

\footnotetext{
${ }^{10} \mathrm{https}$ ///justicehub.org/article/bintou-foune-samake-mali (retrieved 9th March 2016)
} 


\section{Bibliography:}

Badru, Pade (2006) The Spread of Islam in West Africa: Colonization, Globalization, and the Emergence of Fundamentalism Edwin Mellen Press

Bourgeois, J-L (1987) 'The History of the Great Mosques of Djenné' African Arts 20(3): 54-63, 90-92.

Hylland-Eriksen, T (2001) Between universalism and relativism: a critique of UNESCO's concept of culture' in Cowan et al (eds.) Culture and Rights: Anthropological Perspectives Cambridge University Press

Joy, C (2011) 'Negotiating material identities: young men and modernity in Djenné' Journal of Material Culture 16(4) 389-400

Joy, C (2013) The Politics of Heritage Management in Mali: From UNESCO to Djenné Routledge.

Joy, C (2016) 'UNESCO is what? World Heritage, Islam and the Search for a Common Humanity in Mali' Berliner, D \& Brumann, C eds. World Heritage on the Ground: Anthropological Insights Berghahn

Konaré, A (1995) 'Toward More Efficient International Collaboration' African Arts, Vol. 28, No. 4, Special Issue: Protecting Mali's Cultural Heritage (Autumn, 1995), pp. 27-31

Pezard, S \& Shurkin, M (2015) Achieving Peace in Northern Mali: Past Agreements, Local Conflicts, and the Prospects for a Durable Settlement RAND

Soares, B. (2005) 'Islam in Mali in the neoliberal era', African Affairs 105(418): 77-95

UNDP (2015) Preventing and Responding to Violent Extremism in Africa: A Development Approach 
